\title{
Approval Date
}

National Cancer Institute

\section{Source}

National Cancer Institute. Approval Date. NCI Thesaurus. Code C71476.

A date of an official approbation, recognition, or acceptance as satisfactory. 